\title{
Highly Skilled Migration
}

\author{
Brad K. Blitz \\ Kingston University
}

\section{Introduction}

Over the past fifteen years there has been greater interest in the study of highly skilled migrants. This interest can be partially explained by Western dependence on foreignborn experts and the corresponding growth of highly skilled migration within migration streams as well as the consolidation of international and supranational regulatory structures (Cornelius et al. 2001; Iredale 2001; Lavenex 2006). Recent research on the changing nature of work suggests that international flows of highly skilled labor are increasing and that highly skilled workers already move fairly freely between many countries. There are also many political forces influencing the movement of skilled people around the globe: the continued efforts of states to address domestic labor shortages and restock through preferential immigration policies and international recruitment drives are ever more important. This trend has contributed to the development of a small but significant body of literature on professionals and transnational migration.

For social scientists, the unprecedented movement of highly skilled people across the globe calls into question earlier approaches to the study of migration. Where international highly skilled workers were treated in the classical sociological literature on migration as a small population that reflected both the potential for human capital transfers between states and, more controversially, a corresponding "brain drain" from source countries, the realities of transnational migration now complicate this picture (Salt and Findlay 1989; Koser and Salt 1997; Favell 2008). That is not to say that brain drain is a thing of the past - research on the movement of migrants to the United States from Central America and Caribbean countries confirms that overall rates of immigration are above 10 percent, and in some localities above 50 percent (Carrington and Detragiache 1998). However, on a global level, the dynamics have changed significantly.

Recent studies by the OECD point to the rising number of highly skilled people from Asia relocating to the West, as well as a significant increase in the exchange of skilled workers among industrialized countries (OECD 2002). Contemporary movements of highly skilled workers consist of both short- and long-term migrations, return flows, and multiple relocations between advanced states as well as between advanced and developing regions. Also included are well-educated but potentially low-wage or non-earning populations such as students (Khadria 2001), refugees, and asylum seekers (Zolberg 1989), who nonetheless affect national economies and have created national and international markets, for example in social and legal services and higher education, respectively.

This essay is divided into three parts. The first seeks to define the research context. It describes the historical development of highly skilled migration from 1945 to the present day. Particular attention is paid to the expansion of the European Union and other forms of regional cooperation which have given rise to important trade liberalizing agreements, producing a truly global migration market and the policy 
context for much contemporary research. The role of state-sponsored recruitment drives, international return programs, and national immigration policies which give priority to skilled individuals over other categories of migrant are examined. The second part examines the relevance of classical and more recent theories of migration, with particular reference to the literature on professionals, transnational networks, circular and return migration. The third part seeks to establish the profile of highly skilled migrants today and evaluates the measurements used by international agencies and the quality of existing data sources. This essay concludes by considering areas for future research.

\section{Research Context}

The history of skilled migration in the twentieth and twenty-first centuries can broadly be divided into three phases: (1) an early period, characterized by spontaneous and personal movements and motivated primarily by negative push factors as a result of international and intrastate conflict and foreign occupation; (2) an industrial period, during which limited movements and state sponsored recruitment campaigns reflected the needs of growing industrial populations and state policies; and (3) a global phase identified by the growth of transnationalism, regionalization, and development of a global migration market.

From the introduction of immigration controls in the first years of the twentieth century, through both world wars and continuing until the demise of colonialism less than two decades later, well-educated and professional migrants tended to have the status of refugees (Iredale 2001). Their opportunities for employment were dictated above all by the possibility for cultural adaptation, formal and informal traditions of discrimination, and the prevalence of ethnicity based social networks in the receiving state (Vertovec 2000). Thus, while undoubtedly some migrants entered their host countries with high levels of education, most were not necessarily able to convert any specialized knowledge into high-level occupations and there is little written on such individuals in the context of skilled migration.

In the industrial period, Western states welcomed small numbers of highly skilled migrants who were no longer classed primarily as refugees or dissenters but rather educated persons, including technical experts. The futures of international professionals who wished to work abroad were still determined by state policies on immigration and asylum (Zolberg 1989), and this posed a major barrier to their settlement in foreign countries. However, the industrial state was also characterized by its interventionist support for particular sectors, including defense and heavy industry, and while some European states welcomed large populations of unskilled labor (especially from their respective colonies), they also admitted a proportion of highly skilled migrants who filled gaps within key sectors of the economy on an ad hoc basis. Although the effects of the "guestworker" recruitment campaigns were more visible, and have been associated with the height of the industrial expansion and growth in the agricultural sectors in both Europe and the United States (Castles and Kosack 1985; Steinmann and Ulrich 1994; Briggs 2004; 2006; Katznelson 2005; Chin 2007), some skilled migrants were engaged to support areas of great sensitivity and national pride, for example in both the health sector, in the case of the United Kingdom, and in high-status industries such as aerospace or the defense sector in the United States. Though fewer in number, skilled migrants were also central to the arms race as the United States and Soviet Union competed against each other to produce engineers and boost investment in scientific research and development.

The third phase of international skilled migration which is particularly relevant to this article, relates to the period from the 1980s to the present. Until this period, and with the exception of the United States and Canada, where highly educated individuals 
were fortunate enough to relocate through preferential immigration policies, the two most typical profiles of the highly skilled migrant were either the individual refugee who happened to be a highly prized research scientist, academic, or writer and who had been welcomed from Nazi Germany, the Soviet Union, Czechoslovakia, Yugoslavia, or from Chile and Argentina; or the professional who had studied abroad and later emigrated from a low-income country and was thus emblematic of the brain drain affecting the developing world, for example, the archetypal Indian or Nigerian doctor who worked in the British National Health Service. However, by the mid-1980s, several developed countries started to attract highly skilled labor by means of specific immigration policies which no longer focused on ethnic and cultural criteria as recorded in racialist policies (e.g., in Australia) but instead emphasized skills.

The expansion of a global trading regime in the 1990s, and above all the completion of the European Single Market in 1992, the Uruguay Round in 1994 (as well as the collapse of the Soviet Union shortly beforehand), dealt a blow to the statist preference of linking skilled migration to national labor needs and instead heralded a radically new era based on neoliberal competition and distinctly new trends that set it apart from previous periods in history (Lavenex 2006). Castles and Miller (2003) claim that contemporary patterns of migration are now defined by increasing numbers of people who migrate (acceleration), with both different profiles and effects on sending and receiving states (differentiation) and have also had a stark influence on women's economic opportunities (feminization). The increased movement of highly skilled persons around the world has led to the creation of distinctly new categories of migrant. International professionals, in particular, have been among the most privileged and have seen their status enhanced, with many more career options at their disposal then they had only twenty years ago.

\section{Current Immigration Policies to Attract Skilled Labor}

With the emergence of a global neoliberal system, more countries have followed the US lead of setting quotas for skilled migrants (e.g., New Zealand and Germany) but most advanced states have instead relied on a points based system along the lines of the well-established Canadian model. These include: New Zealand (1987), which adopted a mixed approach of quotas and points; Australia (1988); Hong Kong (2006); France (2007); and most recently the United Kingdom (2008). Other countries have introduced de facto points systems, basing entry qualification upon similar criteria but without actually counting up "points." In October 2007, the European Union also proposed a Blue Card scheme, along the lines of the US Green Card, which combines residence and work permits, with the aim of attracting highly skilled immigrants who have at least three years' professional experience.

The use of preferential and points-based schemes has generated a degree of controversy in several developed states, not least because these schemes have been accompanied by tiered policies which delimit options for immigration among lesser-skilled groups. For example, in June 2008 the UK government established a five-tier system which disadvantages unskilled migrants. Moreover, the new immigration policies which emphasize the value of highly skilled migration tend to be accompanied by programs and targets on the return and removal of lesser-skilled migrants who cannot convert their status into more permanent residency. The most notable example of the increasingly divergent immigration paths was the 2006 French Immigration and Integration Act which gave the government new powers to restrict family immigration and set targets for the Ministry of the Interior to remove 25,000 "illegal immigrants." In the United Kingdom, the creation of a new Highly Skilled Migrant Program (HSMP) in 2002 gave rise to additional challenges when it was amended in 2006 and the terms of residence changed retrospectively (House of Lords 2006). 
Table 1 Immigration policies and highly skilled migrant schemes in selected OECD states

Country Immigration Scheme Quotas Points General Conditions Conditions for Permanent Residency

Australia General Skilled $\quad$ No $\quad$ Yes $\bullet$ Aged 18-45
Migration Program $\quad$ High level of English language proficiency

- Recent skilled work experience or Australian qualification

- Qualified in an occupation included in Australia's Skilled Occupation List (SOL). www.immi.gov.au/skilled/

general-skilled-migration/index.htm

$\begin{array}{llll}\text { Canada } & \text { Skilled Worker Class } \quad \text { No } \quad \text { Yes } \quad \bullet \text { Aged 21-49 } \\ & & & - \text { Possess terti }\end{array}$

- Possess tertiary education qualification

- 12 months postgraduate work experience in an occupation listed on the National Occupations Classification (NOC) list

- High level of English and/or French language proficiency

- Adaptability www.migrationbureau.com/ canada/immigration.php

France $\quad$ Skills and Talents $\quad$ No $\quad$ Yes $\quad$ - $\begin{aligned} & \text { If sought after by an employing firm, 3-year } \\ & \text { Skills and Talents Visa can be obtained. }\end{aligned}$

- Demonstrate they will contribute to economic, intellectual or cultural development of France and their home country

- Extra allowance for foreign postgraduate students who qualified from a French institution General Skilled Migration Program. OR

- Must have lived in Australia for at least two years and worked full time for a total period of 12 months in a Specified Regional Area of Australia www.immi.gov.au/skilled/ general-skilled-migration/887/ index.htm

Automatic if General Conditions are met

- Permits are valid for three years in the first instance.

- No residency requirements for those on temporary permits apart from students who apply after earning degrees in France 
Table 1 (continued)

\begin{tabular}{|c|c|c|c|c|c|}
\hline Country & Immigration Scheme & Quotas & Points & General Conditions & Conditions for Permanent Residency \\
\hline $\begin{array}{l}\text { New } \\
\text { Zealand }\end{array}$ & $\begin{array}{l}\text { Skilled Migration } \\
\text { Category (formerly } \\
\text { called General Skills) }\end{array}$ & Yes & Yes & $\begin{array}{l}\text { Two stage application process: } \\
\text { 1) Lodging an Expression of Interest } \\
\text { 2) Invitation to Apply for Residency } \\
\text { Applicants must: } \\
\text { - be in good health } \\
\text { - of good character } \\
\text { - reasonable standard of English } \\
\text { - be under the age of } 56 \\
\text { Extra points awarded for having an offer } \\
\text { of skilled employment in New Zealand, } \\
\text { employment in areas of growth, in an absolute } \\
\text { skills shortage area, or employment within } \\
\text { certain clusters, and outside of Auckland. }\end{array}$ & $\begin{array}{l}\text { No residency requirements but } \\
\text { applicants may receive additional } \\
\text { points for having least two years' } \\
\text { tertiary education in New Zealand }\end{array}$ \\
\hline $\begin{array}{l}\text { United } \\
\text { Kingdom }\end{array}$ & $\begin{array}{l}\text { Highly Skilled Migrant } \\
\text { Scheme }\end{array}$ & No & Yes & $\begin{array}{l}\text { Must either be: } \\
\text { - living in the United Kingdom with } \\
\text { permission to stay ("leave to remain") or } \\
\text { - in an immigration category that allows them } \\
\text { to switch into the highly skilled worker } \\
\text { category } \\
\text { HSMS points awarded for } \\
\text { - age } \\
\text { - qualifications } \\
\text { - previous earnings } \\
\text { - experience in the United Kingdom } \\
\text { - English language ability } \\
\text { - means of support }\end{array}$ & $\begin{array}{l}\text { Five years lawful residence with no } \\
\text { more than } 450 \text { days absence during } \\
\text { that time }\end{array}$ \\
\hline $\begin{array}{l}\text { United } \\
\text { States }\end{array}$ & $\begin{array}{l}\text { H 1-B Visa (specialists) } \\
\text { O Visa (extraordinary) }\end{array}$ & Yes & Yes & & $\begin{array}{l}\text { Five years permanent residence with } \\
\text { absences of up to six months each year }\end{array}$ \\
\hline
\end{tabular}




\section{International Recruitment Campaigns}

The above-mentioned immigration policies have been accompanied by the use of specific recruitment campaigns that reflect the attempt to manage skilled migration by means of both political controls and market forces. These campaigns are often managed between key governmental departments (e.g., health) in concert with ministries of foreign affairs which advertise programs through their consulates abroad. Such campaigns have accordingly generated an international recruitment race where the most advanced states compete with one another to attract talented individuals. For this reason, Sandra Lavenex argues that "skilled migration has become an important element in the external economic policy of the competition state" (2006:35). The United States, Canada, Australia, the United Kingdom, and France, in particular, have created energetic international recruitment campaigns to attract highly skilled medical personnel from South Asia and South Africa to the nursing sector.

From the perspective of the individual, however, this inter-state competition opens up new possibilities, including being able to choose from a range of offers which may not simply relate to working conditions and remuneration but also non-wage benefits such as housing and quality of life issues (Favell 2008) and, crucially, provision for families since some countries are more prepared to award immigration points and provide visas for family reunification. One positive side effect of these recruitment campaigns is the radicalizing effect they have on individuals who feel empowered to take advantage of their privileged status within the global migration market (Ballard et al. 2004).

\section{Regional Cooperation and the Creation of a Global Migration Market}

The main catalyst for the new opportunities generated by a global migration market has been the European Union, which since its inception as the European Economic Community in 1957 has emphasized the right of free movement of people as one of its four essential Rights under Article 49 (formerly Article 48) (Blitz 1999). Regional cooperation and integration in the European Union has set the tone for policy convergence toward international standards and procedures at the global level and within many other regional trading blocs (Lavenex 2006). The effect of this convergence has been felt most acutely on professions that had previously been regulated by the state and which have been liberalized further following the establishment of the General Agreement on Trade and Services (GATS), which covers services provided in 140 economies. Since it came into force in January 1995, the GATS has served to break down some symbolic and substantive trade barriers that had existed above all between the United States, the European Union, and Asia. It covers all internationally traded services such as banking and telecommunications and also includes professional services which are described in the context of "natural persons" present on the territory of another state (WTO 2008). Most important, the GATS requires states to abide by the principle of nondiscrimination and guarantee equal opportunities to service providers from all other WTO members. While the GATS has been more successful in some regions than others, it has achieved some notable achievements, above all in Euro-Atlantic relations.

\section{Other Contemporary Policies}

In addition to immigration policies in advanced economies, it is important to record the growing development of "return of qualified nationals programs" that seek to correct "brain drain" by drawing skilled migrants back home after periods of conflict in countries such as Afghanistan, Iraq, the Great Lakes Region of Africa, and the 
former Yugoslavia. An early example of these schemes was the 1995 initiative by the International Organization for Migration (IOM), which set up a five-year program to strengthen the human resource base of 11 African states including: Angola, Cape Verde, Ethiopia, Ghana, Guinea Bissau, Kenya, Mozambique, Sierra Leone, Uganda, Zambia, and Zimbabwe. This program sought to return and place 631 qualified African nationals in priority public and economic sectors. Similar programs have been aimed at other refugee groups. In 2002, the IOM launched a Return of Qualified Afghans Program (EU-RQA) which aimed at building capacity through short- and long-term placements for 200 qualified Afghans residing in the EU and in Bosnia; specific programs targeted both professionals and key figures in the public administration judiciary who also happened to be minorities.

While these programs are aimed at addressing some of the gaps caused by outmigration and forced migration, overall numbers of participants can be measured in their hundreds and sponsorship is frequently withdrawn after a relatively short period of time - too short to ensure the return of skilled people to post-conflict environments. Overwhelmingly, such schemes have not managed to reverse the "brain drain" that tended to accompany refugee flight and settlement abroad.

\section{Review of Classical and Older Literature}

The expansion of international and global policies that facilitate the transnational migration of highly skilled people has had a profound bearing on the nature of academic writing on this subject. Previously, there was little that specifically addressed highly skilled migrants within the classical canon of migration theory. This is no doubt due to both the relatively small presence of skilled migrants in recent times and the fact that migration theory was forged during the industrial era and reflects the concerns of that period, notably the need for physical labor. Massey puts forward an additional reason and suggests that migration theory was historically tied to the particular economic arguments and social institutions of the industrial period, which were above all macro-sociological in nature (Massey et al. 1998). It is nonetheless helpful to outline some classical approaches to the study of migration to assess how they may advance our understanding of the processes of skilled migration before considering the new literature on networks, circular migration, and professionals.

\section{Historical Trends and Levels of Analysis}

One of the emerging themes from the classical literature which is relevant to this study is a powerful critique against mechanistic explanations for migration in favor of multi-leveled analyses of flows and the decisions that encourage them (Zolberg 1989). Thomas Faist (2000) defines the three main levels of analysis which characterize studies of international migration and are offered as ideal-types. These are: the micro level (individual autonomy behind migration choices); the state level (politicaleconomic-cultural structures such as states); and the meso level, which describes the set of social and symbolic ties. Until the 1970s, migration theory was heavily influenced by approaches that focused either on individualistic explanations at the micro level, where migration was the result of personal choice and where individuals weigh up the costs and benefits of moving, based on their skill sets (Massey et al. 1993; 1994). This approach gave way to more structural explanations in the 1970s, when scholars placed greater emphasis on inequalities produced by migration, which were often explained as a regional phenomenon with groups of people moving to areas where wages are higher; hence, the growth of studies on "brain drain." Although the term "brain drain" was coined by the Royal Society and first applied to migration from 
postwar Europe to North America (Cervantes and Guellec 2002), there was a surge of interest in the problems of human capital flight from the developing world to advanced economies.

\section{Laws and Theories of Migration: Geography and Push-Pull Approaches}

Ernest George Ravenstein has been cited as one of the principal pioneers in the study of migration, whose work has influenced generations of scholars. Among his most significant studies is the 1885 article on the "Laws of Migration," in which he attempted to explain and predict patterns of migration both within and between states. Using census data from the late nineteenth century, Ravenstein sought to describe trends in the absorption (countries of immigration) and dispersion (countries of emigration) of migrants, which he set out most famously in seven laws. His approach called attention to essential, interconnected features of international migration, which include the geographical categories of space and distance. Half a century later, Ravenstein's formal model was recast by Samuel Stouffer (1940) who emphasized the importance of opportunities in his own "Law of Intervening Distances." According to Stouffer, migration could be explained not only by individuals' preferences either to remain in their place of origin or leave for a new destination but also by the opportunities they might encounter en route to the potential destination.

While geographical proximity and opportunities were important factors which helped to explain some instances of migration, it was above all the work of Everett Lee which identified a particular dynamic between sending and receiving states and which helped to shed light on conditions that affect migrants' choices. In "A Theory of Migration" (1966), Lee developed Ravenstein's and Stouffer's predictive models to consider a broader number of factors which influenced the decision to migrate. $\mathrm{He}$ devised the "push-pull theory" of migration, which considers the role of both incentives and disincentives for migration in countries of both origin and reception. According to Lee, the greater the perceived difference in the net forces of attraction in places of origin and destination, the more likely it is for people to migrate. One of Lee's central findings, which is most relevant to this article, concerns the profile of migrants who respond to push or pull factors, respectively. Lee found that migrants who respond primarily to pull factors in the place of destination tend to be positively selected (e.g., by age, education, skills, or motivation) and thus also include highly skilled individuals, among others. By contrast, those responding primarily to push factors in the place of origin tend to be negatively selected and include forced migrants such as refugees, as well as low-skilled economic migrants.

The push-pull approach to migration has been a central feature in the academic study of migration for forty years but has nonetheless generated several important criticisms. Scholars note that the approach is far from universal in application - why is it that migrants in some regions opt to leave but not in others where conditions are objectively as bad, if not worse? Further, some claim that the approach is simply too rigid: the push-pull model ignores the historical context in which migration takes place (Zolberg 1989). A similar complaint is the lack of attention paid to the political system. According to Zolberg, one pivotal reason why migration theory cannot explain why the vast majority of the world's population does not relocate is due to the primacy of the sovereign state, whose boundaries are upheld by international law. For political scientists, the nature of international migration is best explained in the context of a system of interacting states where the potential mobility of labor is restricted by competing interests. This includes both receiving, and limiting the flows of, migrants to satisfy labor needs on the one hand, and domestic political interests (e.g., anti-immigrant opinion) on the other. Several other commentators have argued that the push-pull approach simply does not take into consideration the significance of 
governmental policies on immigration and other structural conditions at origin and destination that shape migration (Boyd 1989; Kritz et al. 1992; Portes and Rumbaut 1996). Finally, the push-pull model also fails to account for individual differences in migration choices and, perhaps most important, no longer captures the empirical reality of migratory movements especially in a highly globalized world. For example, Mahroum (2002) claims that other factors, such as taxation, studying abroad, quality of work, openness in communication, play an important role in the choice of highly skilled migrants to relocate overseas. In today's context, the push-pull approach is challenged by the substantial evidence of return flows and active diaspora networks. Indeed, the prevalence of millions of dollars of remittances suggests an alternative preference of capital mobility over actual human mobility (Vertovec 2000; Overbeek 2002).

\section{Economic Arguments, Brain Drain, and Inequality}

Scholarly writing on brain drain emerged in response to neoclassical models which treated the movement of labor (i.e., immigration) as a positive action for sending countries with no adverse affect on the welfare of those left behind.

In the 1970s and early 1980s, however, several economists identified brain drain as a major impediment to the development of sending states and found that the outmigration of skilled people directly lowered economic growth in source countries (Bhagwati and Hamada 1974). In the 1980s, a new branch of economic thinking associated with endogenous growth theory painted an even more pessimistic picture. Since endogenous growth theory emphasizes the development of human capital (Romer 1990; 1994) and innovation for growth (Grossman and Helpman 1991), the main problem with brain drain is not simply the removal of skills but the polarization that it creates within source countries (Straubhaar and Wolburg 1999). In this model, brain drain reduces the wages of the unskilled population while increasing the wages of remaining skilled workers and thus creates greater inequality, which in turn sows the seeds for exclusion and poverty to take root (Lowell 2002).

More recent work on migration to emerge from economic theory has reexamined the motivation for migration. While such studies have focused on the primacy of wage differentials as activating reasons for migration (Alonso 1976; Cain 1976; Stark 1991), apart from some regional studies of brain drain, few macro-level investigations have explicitly considered the impact of skilled migration. However, the logic of treating migration as a mechanism for redistributing labor between states is relevant to studies of skilled migration, not least for the potential insights into the rationale for migration in the first place.

Several researchers have adapted neoclassical economic models of the labor market and have drawn different conclusions (Sjaastad 1962; Harris and Todaro 1970; Todaro 1976). For example, Harris and Todaro (1970) created a long-standing framework for understanding patterns of rural-urban migration where the decision to migrate is not based on wage differentials, as suggested in push-pull and classical economic formulations, but rather on the expected income differentials between rural and urban areas. This helps to explain why migrants are prepared to move to areas of high urban unemployment.

Since Harris and Todaro, other scholars have recognized limitations with earlier cost-benefit models. Rather than treat migration as the aggregate of individual choices, they have drawn upon empirical research on the nature of migration flows to highlight the importance of families and networks (Massey 1987; Zolberg 1989). According to the new economics on migration, individuals act within family structures and households not only to maximize their expected income but also to minimize the risks to 
their economic well-being (Sana and Massey 2005). One way of doing so is by diversifying the allocation of family labor by sending relations to different locations (Massey 1998:14-15). As Light and Bhachu (1993) record, there are several opportunities not just for states but also for individuals and family units. Migration introduces the possibility of exploiting a region's competitive advantage: "international migration is especially effective because international borders create discontinuities that promote independence of earnings at home and abroad. Good times abroad can match bad ones at home, or vice-versa" (Light et al. 1989:2).

Linked to the above approaches, a wave of critical migration theory emerged from Marxist analyses which focused on the dynamics of production and the reproduction of labor (Piore 1979; Castles and Kosack 1985). This literature responded to the changing nature of Western industrial states and considered the role of exploited unskilled and low-skilled migrants who filled marginal niches as well as large sectors of the economy. In spite of their focus on low-skilled labor, several aspects of critical migration theory are important to this study; for example, the dual labor market theory's emphasis on the dynamics of international recruitment and the underlying logic of the state as a recruiter of short-term labor and as an international operator that can exploit the global pool of talent to meet national demands.

According to dual labor market theory, the economy is divided into primary and secondary sectors, which broadly relate to high-status/low-status occupations. Historically, the secondary sector was characterized by short-term employment relationships with little or no prospect of internal promotion and wages determined by market forces. Those who occupied this sector consisted of low-skilled or unskilled workers in support roles, or manual or service industries (e.g., clerks, manual labor, waiters, etc.). Michael Piore's work on the dual labor market and, specifically, migration from underdeveloped rural areas to industrial societies has contributed to our understanding of brain drain. In his ground-breaking Birds of Passage: Migrant Labor and Industrial Societies (1979), Piore argues that emigration from rural areas to advanced states is generated by forces inherent in the nature of industrial economies. His work has been linked with the concept of brain drain since he forcefully challenges the claim that the out-migration of people from poor regions is beneficial to both sending and receiving societies and questions whether migration enables individuals to develop skills necessary for the emergence of an industrial labor force in the home country (Piore 1979; 1983). His conclusions have been supported by Saskia Sassen (1991), who discusses the polarization of labor markets and creation of upper and lower circuits of capital and argues that many migrants are locked into poorly paid jobs in receiving states where economic conditions preserve established occupational hierarchies, most notably in service industries. The relevance of this body of writing for skilled migration lies above all in the growing evidence of inequality of opportunity between migrant groups which has been sustained by selective and hierarchical immigration policies. For example, in their study of the movements of skilled workers to the United States, Mattoo et al. (2005) found striking differences among highly educated immigrants from different countries in terms of the types of jobs they obtain: immigrants from Latin America and Eastern Europe are more likely to end up in unskilled jobs compared to immigrants from Asia.

An additional body of critical writing on migration can be found in the application of world systems theory. Rather than focus on a two-level division between developed and underdeveloped states, world systems theory assumes that migration is facilitated by cultural, linguistic, administrative, and communication links and results from imbalances between three distinct zones (core, semi-periphery, periphery). While this literature is relevant to brain drain, it is important to note that the way in which migration is conceived encompasses both the place of origin and destination as a "unified space" rather than a process between two destinations. Migration is associated 
with other social and political processes, including colonization/decolonization, trade (Wallerstein 1974; Petras 1981; Sassen 1988; 1991; Portes 1995), and the creation of state policies on immigration (Zolberg 1989); hence the importance to the study of brain drain.

\section{Networks and Transformative Approaches}

Closely associated with the literature on world systems approaches is a recent body of writing on networks (Vertovec and Cohen 1999). Like world systems approaches, the study of networks has broken down the traditional distinction between place of origin and destination, as well as the micro-macro model, to examine the impact of societal and political factors on decisions to migrate. As Charles Tilly (1990) notes in his review of immigration into the United States, networks migrate. This finding is supported in Douglas Massey's influential theory of "cumulatively caused" migration which has developed our understanding of the relationships between migrations, both in terms of time sequence and substance. According to Massey, migrations create networks, which then generate new migrations. Networks in this context are "sets of interpersonal ties that connect migrants, former migrants and non-migrants in origin and destination areas through the bonds of kinship, friendship and shared community origin" (Massey 1998). The logic is that networks help to reduce the risks and costs of migration and support new immigrant flows.

As outlined in the growing literature on social capital (Putnam 2000), there are, of course, many different types of network. In the context of highly skilled migrants, Vertovec claims that high occupational groups rely more on networks of colleagues and less on kin based networks than unskilled workers. Irrespective of the reason for the first migration, Massey claims that subsequent migratory processes become "progressively independent" from the original conditions (Massey 1988; 1989; Massey et al. 1993). For this reason, Portes (1995) suggest that migration can be conceived of as a process of network building.

In spite of its richness, there are some important shortcomings in the literature on network based approaches to the study of migration. First, there is the problem of economic saturation. As Gregory has noted, job opportunities exercise a "restraint on the volume of migration" (1989:17). Further, there is the assumption that networks are conflict-free, a condition which has been called into question by evidence of return of qualified national schemes in transitional states (Blitz 2005b) as well as more critical studies on social capital that note the power of corruption and exclusion of others (Putzel 1997; Portes 1998; Gargiulo and Benassi 1999). Portes and Borocz (1989) have also noted that while some migrants may be advantaged by migration, many are handicapped as a result of closed shop practices of trade unions, racial discrimination, and lack of legal status. The above problems have been reiterated by De Haas (2008), who claims that scholarly discourses on transnational engagement, which is often described as self-help development from below, "shift attention away from the relevance of structural constraints and the important role states and other institutions play in shaping favourable general conditions for social and economic development to occur" (2008:49). Evidence in support of the power of structural and discriminatory practices, including racism, has been offered by Pethe (2007) who, in her study of the German scheme for information and computing technology (ICT) professionals, found that the majority of highly skilled migrants entered the country not via intra-company transfers or as highly skilled specialists, but rather as refugees who then enjoyed little market success. Finally, it should be recognized that there are essential individual skill sets which determine how well migrants may access such networks, including interpersonal skills and self-confidence (Williams and Baláž 2005). 


\title{
Changes over Time and Current Treatment of Highly Skilled Migration
}

\author{
Internal and External Dynamics: Skilled Migration and Brain Drain
}

There have been several groundbreaking studies which have attempted to put skilled migrants, including professionals, on the academic map. One of the most widely cited is John Salt's (1997) paper for the OECD, entitled, International Movements of the Highly Skilled, in which he identified several typologies of skilled migrant. A particularly original feature of Salt's paper is his use of empirical information to demonstrate how the interaction between direct recruitment from the external labor market (ELM) and from within corporate internal labor markets (ILMs) "creates a selective and highly managed flow of skills into a modern economy” (Salt 1997:4).

Salt has been among the most prolific scholars to write on skilled migration in the UK and OECD over the past decade (Salt 1992; 2005; Koser and Salt 1997; Salt and Millar 2006) and his work has been accompanied by several important reviews and comparative studies. For example, Cornelius et al.'s (2001) volume on international migration in both sending and receiving states considers the tension between advanced industrial societies' dependence on foreign scientists for their economic growth and the realization in the emerging economies of India, China, and South Africa of the need to stem the outflow of their own home-grown professionals. Similar concerns about the outflow of skilled migrants from developing countries have been voiced (Carrington and Detragiache 1998). Some studies have focused on particular sectors, such as nursing professionals in South Africa (Meyer 2002), various highly educated groups to the Philippines (Alburo and Abella 2002), health and education professionals in the Caribbean (Thomas-Hope 2002), students and IT experts leaving India (Khadria 2001; 2002) and the aerospace industry in the UK (Millar and Salt 2008).

On a macro level, Lowell and Findlay argue that the net impact between sending and receiving states over the loss and receipt of skilled persons, respectively, is a balance of direct and indirect effects. Although they noted that brain drain is the most direct effect - and often an overwhelmingly negative one for the economic growth of the sending country - they also find that the loss of such educated workers sets in play a number of forces that can increase economic growth through three feedback mechanisms. Indeed, this is one of the central arguments for return of qualified nationals programs.

Return migrants, in particular, bring back their skills and work experience from abroad, thus boosting productivity. Expatriates who remain abroad contribute money via worker remittances; and many observers claim that their transfer of knowledge or technology to developing countries can increase productivity and economic development. (Lowell and Findlay 2002:1)

The increase in productivity may be felt at many levels. In the case of individuals, it is suggested that the act of emigrating to higher-wage countries encourages people to pursue higher education in anticipation of finding better-paid work abroad (Docquier and Rapoport 2003). In the case of states, both large and small numbers of migrants affect the economic structure in ways which, paradoxically, may be beneficial. The idea of an optimal level of emigration is put forward by Lowell and Findlay, who draw upon economic research over the past decade on the "beneficial brain drain." For example, Mountford's (1997) study of brain drain in developing countries found that when migration is not a certainty, brain drain may increase average productivity and equality in the source economy. Similarly, Beine et al. (2008) noted in their study of more than 50 states that most countries combining low levels of human capital and low migration rates of skilled workers tended to be positively affected by the brain drain. 
Other studies on brain drain have exposed the complexity of international migration flows. This research has generated a complicated picture of skilled migration with wide regional variations in terms of geographical scale (Skeldon 2005), intensity and effect at both source and receiving countries (Docquier et al. 2007). For example, examining migration rates to the US by level of educational attainment, Adams (2003) claims that even though migrants may be highly educated, international migration does not tend to take a large proportion of the best-educated. Using data on 33 source countries in which educational attainment data can be estimated, he found that in 22 of them, less than 10 percent of the tertiary-educated population of laborexporting countries had migrated (2003:18). The costs and benefits of brain drain to source countries is another theme which has appeared in scholarly writings. According Mattoo et al. (2005), these costs include investment at source since the quality of reception enjoyed by skilled migrants in host countries is partially due to the quality of human capital they offer; hence the relevance of government expenditure on education in sending countries.

Research into the longer-term effects of brain drain has also produced some counterintuitive conclusions. Faini (2007) found that skilled migration is unlikely to enhance and may actually depress the flow of remittances to the source country since even though highly skilled migrants often earn higher wages this does not translate into more remittances sent home because these migrants tend to stay longer in the host country and are also likely to reunite with family members. In another study of Indian software companies, Commander et al. (2004b) concluded that out-migration does not necessarily impact on the performance of firms in sending contexts, as measured by the change in turnover per worker and the change in the employment size of the firm (Commander et al. 2004b:24).

\section{Professionals, Circular Migration, and Brain Gain}

Some of the most important new literature on highly skilled migration deals with the place of professionals in the global migration market. Robyn Iredale's (2001) work on professionals has made one of the most significant contributions to the study of highly skilled migration. Iredale describes five typologies of skilled professional migration: (i) by motivation - which includes decisions at both the individual level (e.g., through "ethical emigration" or "brain drain") and the state and macro levels ("forced migration," "government induced," and "industry led"); (ii) by nature of source and destination (e.g., from less developed countries to post-industrial states); (iii) by channel or mechanism (e.g., through internal labor markets); (iv) by length of stay (including both temporary and circular movements); and (v) by the mode of incorporation - whether or not migrants are tolerated, treated positively, or negatively received in the host state (Iredale 2001:16-19). She argues that formal procedures for recognizing the skills of permanent immigrant professionals are breaking down as a result of "fast-track" processes for assessing the skills of temporary professional migrants and consequently, professions have become transnationalized. Further evidence in support of Iredale's thesis can be found in Salt and Millar's (2008) work on the aerospace industry and Adrian Favell's (2008) sociological study of urban cosmopolitanism among elite "eurostars" in London, Amsterdam, and Brussels.

Additional research on the international recruitment of both doctors and nurses (Buchan 2002; Buchan et al. 2003; Ballard and Lawrence 2004; Ballard et al. 2004; Blitz 2005a) has highlighted the growing importance of government-sponsored initiatives and societal factors which influence the decision of these experts to seek work abroad. Ballard et al. (2004) claim that relocation is not an automatic process but there are various stages characterized by instigating, facilitating, and activating factors which operate at the micro, meso, and macro levels, that ultimately determine 
why highly specialized professionals relocate as and when they do. Further research on the role of non-wage factors such as greater choice, autonomy in the workplace, job satisfaction, diversification, the attraction of foreign travel, and the importance of post-materialist values in the construction of elite careers is also worthy of mention (Inglehart 1971; 1977; 1990; Blitz 2005a).

The growing body of literature on circular migration and brain gain has attracted much attention from both scholars (Mahroum 1999; Pellegrino 2001; Regets 2001; Saxenian 2002; Salt 2005; Vertovec 2007) and international agencies, above all the OECD and the European Union (Cervantes and Guellec 2002; OECD 2002). Indeed, circulation is now central to the European Union's Global Approach to Migration, which aims to correct the potentially long-term effects of an East and Southeast European brain drain and also address the domestic challenges faced by states that have been receiving non-EU nationals within their borders. Other international policy actors have given particular attention to the potential of circular migration of skilled labor (see International Organization for Migration 2005; Williams and Baláž 2005; Vertovec 2007). For example, the recent report of the Global Commission on International Migration (GCIM 2005) called upon states to consider the developmental opportunities created by multidirectional patterns of migration and recommended that "countries of destination can promote circular migration by providing mechanisms and channels that enable migrants to move relatively easily between their country of origin and destination" (GCIM 2005:31).

Vertovec claims that research on circular migration has focused on "unregulated systems" where "migration flows have been established by migrants themselves between homelands and places of work, as opposed to formal or regulated systems by which employers and states collaborate to recruit, transport and employ workers from abroad" $(2007: 5)$. This research has focused largely on the migration of groups in close proximity to the mainland of the US and Canada, such as Puerto Ricans and Mexicans (Massey 1987; Massey and Espinosa 1997; Duany 2002; Basok 2003) although there are also important articles on other regions, including the European Union and Central Europe (Linková and Henderson 2003; Blitz 2005a; Williams and Baláž 2005), Russia and the former Soviet Union (Mukomel 2008).

\section{Highly Skilled Migrants Today: Definitions, Typologies, and Profiles}

As evidenced from the above literature review and historical account, highly skilled migrants do not fall into a defined nor a homogeneous group; however, there are some common features one can identify. Hertel's acclaimed Global Trade Analysis (1997) records that skilled migrants may include managers, professionals, engineers, scientists, teachers, and bureaucrats, as well as many other occupations. They tend to be differentiated from unskilled or production workers, such as tradespeople, clerks, sales clerks, industrial workers, and farm hands by virtue of their high levels of education and relatively scarce skill sets. Vertovec (2002) argues that while there is a diverse range of highly skilled migrants, it is nonetheless possible to identify commonalities, for example in terms of their occupational entry criteria. He defines highly skilled migrants as those individuals who possess a tertiary degree or have acquired extensive specialized work experience, such as architects, accountants and financial experts, engineers, technicians, researchers, scientists, chefs, teachers, health professionals, and IT specialists. Recognizing the diversity of highly skilled migrants internationally, the OECD, European Union, and UN agencies have nonetheless employed an operational definition based on length of time abroad. For practical purposes these agencies define short-term migration as cross-border movements of between three and twelve months. Long-term migration is considered to be over twelve months and may last several years. 
What is the profile of highly skilled migrants? While the above-mentioned occupational categories shed light on the qualifications and occupations of people who might be considered highly skilled migrants, they are not specifically limited to migrants. Moreover, when they do apply to migrants, the above classifications do not inform our knowledge of the conditions which facilitate their international mobility. As Salt (1997) notes, there are many social and political aspects associated with the experience of international migration and which provide an insight into the context in which cross-border mobility takes place, hence the need for further categorization (see also Koser and Salt 1997). To this end, he identifies several typologies of temporary highly skilled migrants who share one unifying feature: they tend to be few in number relative to the demand for their services. For this reason, Salt emphasizes their "low elasticities of supply" (1997:5).

The first category of corporate transferees refers to one of the largest collections of transnational migrants. Corporate sector workers who are sent abroad by their companies - or who choose to be sent abroad - differ from traditional types of migrant in that these individuals relocate within their own internal labor market (ILM). Their moves, for example from one technical department or sales region to another, tend to reflect the globally defined organizational structure of their employers and arguably there may be less competition to migrate within such a market. In addition, Salt describes specialized technicians - or "visiting firemen" as he calls them - who are brought in on an ad hoc basis to address particular technical problems, manage projects, or oversee major change within an organization. Project specialists are similarly described as experts who are hired for a temporary period, and who tend to relocate within corporate ILMs, for example in large-scale construction and engineering projects in developing centers (such as the Gulf region and China) which are managed by multinational construction firms or architects.

Other highly skilled migrants include professionals, who tend to be directly recruited into the external labor market (ELM), such as medical and health specialists, legal and educational experts who may be employed abroad by international organizations or NGOs. Such professionals are similar to international consultants who provide services on behalf of contracted consulting firms and may otherwise be described as "business professionals," in that many have specialized sectoral knowledge and hold advanced degrees, e.g., MBAs. Other highly skilled individuals seek to exploit the opportunities for career development and training by securing employment abroad; for example, nurses have found that by working overseas in another health system they are more likely to be promoted when they return home (Blitz 2005a).

Two other important categories of highly skilled international migrant include military personnel who have particular specializations that may also have a civilian function (e.g., in medicine, technology, research and development) and academics, researchers, and a significant number of students who seek to study abroad for short periods of time or as part of the growing market in international higher education (Khadria 2001; Skeldon 2005). Finally, Salt includes categories of small numbers of specialized but influential migrants in the form of clergy and missionaries and entertainers, sportspeople, and artists; added to this list are the independently wealthy and celebrities, who are able to relocate and settle abroad for short or long periods of time.

For the purposes of cross-national comparisons, UN agencies, the OECD and national statistical agencies use the classification systems known as the International Standardization of Occupations (ISCO-88 or ISCO-88 COM in the case of the European Union), which provides a system for recording labor market data. ISCO-88 organizes occupations into a multileveled framework with jobs appearing at the lowest level in the schema. Jobs are defined as a set of tasks or duties designed to be executed by one person and which are then subdivided into occupations according to the degree of similarity in their constituent tasks and duties (Elias and Birch 1994; United Nations Department of Economic and Social Affairs Statistics Division 2003). Further evidence 
of skilled migration may be gleaned from the presence of highly educated people and individuals classified with high-status occupations, irrespective of their employment situation. It is important to recall that highly educated persons who also happen to be refugees and asylum seekers may nonetheless be present and recorded in immigration statistics even if they do not feature in labor market data. Arguably, the presence of highly skilled migrants, including asylum seekers and refugees, may be inferred by the stock of highly educated foreign-born labor in both advanced and developed economies, as illustrated in Table 2.

Table 2 Foreign born labor present in OECD states for 10 years or less

\begin{tabular}{lccc}
\hline & \% low education & \% intermediate education & \% high education \\
\hline Austria & 2.5 & 51.4 & 23.1 \\
Belgium & 32.2 & 24.9 & 42.9 \\
Czech Republic & 11.6 & 62.8 & 25.6 \\
Denmark & 27.3 & 33.5 & 39.2 \\
Finland & 30.5 & 51.0 & 18.5 \\
France & 40.7 & 25.6 & 33.7 \\
Germany & 32.7 & 41.0 & 26.3 \\
Greece & 48.3 & 39.3 & 12.4 \\
Hungary & 8.2 & 69.7 & 22.0 \\
Ireland & 14.6 & 37.7 & 47.7 \\
Italy & 45.5 & 43.6 & 10.8 \\
Luxembourg & 21.2 & 27.2 & 51.6 \\
Netherlands & 25.9 & 45.4 & 28.7 \\
Norway & 17.5 & 46.5 & 36.0 \\
Poland & 14.4 & 55.8 & 29.8 \\
Portugal & 55.9 & 27.5 & 16.6 \\
Slovak Republic* & & & \\
Spain & 42.3 & 35.9 & 21.8 \\
Sweden & 21.4 & 40.3 & 38.3 \\
Switzerland & 23.9 & 33.9 & 42.2 \\
United States & 34.1 & 35.1 & 30.8 \\
EU15 average & 33.8 & 41.9 & 24.3 \\
OECD average & 28.7 & 41.4 & 29.9 \\
\hline
\end{tabular}

* No information available.

Source: OECD (2008).

Table 2 also provides some useful information on the profile of such migrants: in OECD states, foreign nationals tend to have a particularly high level of education most are likely to be middle to highly educated and are thus attractive to other states where they may make a significant contribution. This claim is supported by the recent finding by Jennifer Hunt and Marjolaine Gauthier-Loiselle that even marginal increases in the number of immigrant university graduates may have a significant impact on levels of innovation. Using patents issued between 1950 and 2000 as a measure of innovation, Hunt and Gauthier-Loiselle found that just a 1 percent rise in the share of immigrant university graduates increased patenting by $8-15$ percent and even more for those with postgraduate qualifications by 15-33 per cent (Hunt and GauthierLoiselle 2008).

The desirability of such migrants is supported by data from the OECD database on immigrants and expatriates in 2000-1, which records that OECD countries including the United States, Canada, Australia, France, the United Kingdom, and Germany are now net importers of highly educated workers (Dumont and Lemaître 2005). 
Like refugees, the presence of women is also often omitted from migration data (Kofman 2000). Recent statistical studies which draw on the UN's Gender Empowerment Measure, a measure of inequalities between men's and women's opportunities in a country, confirm that women make up a significant proportion of professionals in their home states and constitute an important source of highly skilled and mobile labor, especially from lower-income states (Dumont et al. 2007). This fact is further illustrated in the data produced by Eurostat, which record high levels of female participation in the ICT sector in the new EU member states in eastern and central Europe and suggest that women from these countries figure substantially in these migration flows. In addition, Khadria (2002) has found a substantial number of Indian women occupying high-end occupations in US education, when compared with other immigrants in science and engineering. These findings, when taken into consideration alongside OECD data on emigration rates, especially from the developing world to more advanced centers, and recent statistics on educational levels of emigrants, call for greater gender inclusive measures of international skilled migration that recognize the place of women in this stock of potential migrants. Without referring to actual cross-border movements, Table 3 on the global engagement of women in technical and professional fields demonstrates the potential source of female mobile labor.

\section{Global Estimates of Highly Skilled Migrants}

There are no accurate data for the numbers of highly skilled migrants in the international system, something that has proven to be a major challenge to empirical investigations (Salt 1997; Adams 2003; Commander et al. 2004a; Skeldon 2005). To date, researchers have had to rely on composite statistics produced by the OECD, European Union, ILO, and other UN agencies and based largely on European and national sources. However, these sources only offer a restricted view on the volume of skilled migration since most labor-exporting countries do not collect data on their own migrants (Adams 2003). Among the most important studies is the report by Parsons et al. (2007), which sought to quantify the international bilateral movements (both origin and destination) of migrants using a combination of census data and labor market surveys from 226 countries. Their research inspired further studies, most notably by the OECD.

In addition, research on "brain drain" has provided a complementary insight into patterns of out-migration by skill set, which in turn has informed our understanding of bilateral - but not necessarily transnational - migration flows. Other important studies include research by William Carrington and Enrica Detragiache (1998) for the IMF on rates of emigration in 60 countries which affirmed the relationship between tertiary educational levels and high rates of out-migration, although there remain qualitative differences between educational levels (Adams 2003). The Carrington and Detragiache study was followed by the Docquier and Marfouk (2006) analysis of emigration rates for 195 countries in 2000, which drew particular attention to the negative role that local economic conditions play as barriers to international migration. Their conclusion was that states with the highest rates of emigration tended to be middle-income countries where people had both the incentives and means to relocate. Docquier and Marfouk (2006) also identified strong disincentives against emigration from high-income countries and noted that brain drain, while a global phenomenon, had marked regional implications since individuals in low-income countries faced many financial pressures which made the transfer of human capital problematic and deterred them from migrating.

As of 2007, the OECD had compiled extensive statistical data on international migration that allow for a detailed but incomplete picture of the bilateral movement 
Table 3 Female technical and professional workers in selected developing and low-middle-income countries

\begin{tabular}{|c|c|}
\hline Country & $(\%$ total $) *$ \\
\hline Bangladesh & 12 \\
\hline Bolivia & 40 \\
\hline Botswana & 51 \\
\hline Brazil & 52 \\
\hline Brunei Darussalam & 44 \\
\hline Cambodia & 33 \\
\hline Chile & 52 \\
\hline Colombia & 50 \\
\hline Cuba & 62 \\
\hline Dominican Republic & 51 \\
\hline Ecuador & 48 \\
\hline Egypt & 30 \\
\hline El Salvador & 45 \\
\hline Ethiopia & 30 \\
\hline Malaysia & 40 \\
\hline Malta & 38 \\
\hline Mauritius & 43 \\
\hline Mexico & 42 \\
\hline Moldova & 66 \\
\hline Mongolia & 54 \\
\hline Morocco & 35 \\
\hline Namibia & 55 \\
\hline Nepal & 19 \\
\hline Occupied Palestinian Territories & 35 \\
\hline Oman & 33 \\
\hline Pakistan & 26 \\
\hline Paraguay & 54 \\
\hline Peru & 46 \\
\hline Philippines & 61 \\
\hline Sri Lanka & 46 \\
\hline Syrian Arab Republic & 40 \\
\hline Tanzania, United Republic of & 32 \\
\hline Thailand & 54 \\
\hline Trinidad and Tobago & 53 \\
\hline Vietnam & 51 \\
\hline Yemen & 15 \\
\hline
\end{tabular}

* Data refer to the most recent year available between 1994 and 2005.

Source: UNDP (2007).

of highly skilled migrants within the OECD states. By selecting data on residence, birth abroad, and nationality it is possible to construct estimates of highly educated migrants who are registered as living in another state. This information, however, still provides a partial estimate of highly skilled migration within the OECD area since some countries are not included and there are other important discrepancies in the recording of data and their application to the target population. There are also important methodological considerations. As noted by Tyers et al. (2006), the use of census data is problematic because long census cycles tend to underrepresent migrants who may not be registered for census purposes or who are living in a receiving country "undocumented," even over longer periods. In addition, many population registers of foreigners do not record departures and therefore outflow data are less reliable. 
Table 4 Estimates of highly skilled migrants in OECD states based on birth abroad and levels of educational attainment

\begin{tabular}{lr}
\hline Country of Residence & Total \\
\hline Australia & 466,551 \\
Austria & 50,290 \\
Belgium & 95,364 \\
Canada & 567,235 \\
Czech Republic & 19,823 \\
Denmark & 34,652 \\
Finland & 11,571 \\
France & 380,834 \\
Germany* & - \\
Greece & 67,890 \\
Hungary & 15,098 \\
Ireland & 74,628 \\
Italy* & - \\
Japan & 279,610 \\
Luxembourg* & 21,772 \\
Mexico* & - \\
Netherlands* & - \\
New Zealand* & - \\
Norway & 30,905 \\
Poland & 8,583 \\
Portugal & 29,898 \\
Korea & 45,355 \\
Spain* & - \\
Slovak Republic & 4,130 \\
Sweden & 90,131 \\
Switzerland & 170,851 \\
Turkey & 40,915 \\
United Kingdom* & - \\
United States & 353,7929 \\
\hline &
\end{tabular}

* No information available.

Source: OECD (2008).

Further, as Salt notes, the use of tertiary educational qualifications as a measure of highly skilled migration is in itself not an accurate indicator of migration status since many graduates are not in highly skilled jobs. The same applies to refugees and many migrants from lesser developed regions. Finally, several categories used for statistical research purposes (for example by means of censuses, population registers, and numbers of visas) do not always capture the nature of work performed and, in spite of the use of ISCO classifications, the recording of tasks performed in new fields may differ from one country to another, complicating the process of comparative analysis. Table 4, therefore, only provides an indication of levels of highly skilled migrants in some of the OECD member states.

\section{Estimates of International Professionals}

While the data on highly skilled migrants present an incomplete picture of global flows, greater effort has been spent recording the movements of professionals, a 
growing subset of international highly skilled migrants. Among the most important sources is the EU's Eurostat Labor Force Survey. It should be noted that liberal professionals, namely individuals who occupy positions that require formal training in the liberal arts or sciences, are by definition frequently associated with regulatory and autonomous bodies that license or certify the right to practice in a particular state (e.g., Bar Associations, Medical Councils, and other professional societies) and hence there are additional sources of statistical information. Newer fields such as those in ICT are not subject to much regulation (Iredale 2001) and therefore are not reported accordingly. Further, as noted in recent academic research on professionals, the importance of governmental policies as catalysts for skilled migration flows has further aided the process of establishing quantifiable figures on the numbers of professionals moving between states and demand for skilled labor. For example, in July 2008 the German government approved a plan to attract highly qualified foreigners to fill approximately 400,000 identified posts (International Herald Tribune 2008). Classic countries of immigration such as the United States, Canada, and Australia actively seek highly skilled people for permanent settlement and are able to provide relatively accurate data on the immigration status of professionals. Their motivation for gathering such data is sustained by their recognition that foreign professionals play a critical role in their national economies. To illustrate this point, it is helpful to recall that approximately 900,000 highly skilled professionals - approximately one-sixth of the total American IT labor force - entered the US labor market between 1990 and 2000 under the H-1B visa program (OECD 2002).

In 2000, Peter Stalker estimated that there were 1.5 million professionals from developing countries in the advanced industrial states. Further information may be gleaned from the OECD's data on immigrants born abroad by occupation, which provides a more detailed accounting of all types of professionals in the OECD area (see Table 5 and Figure 1).

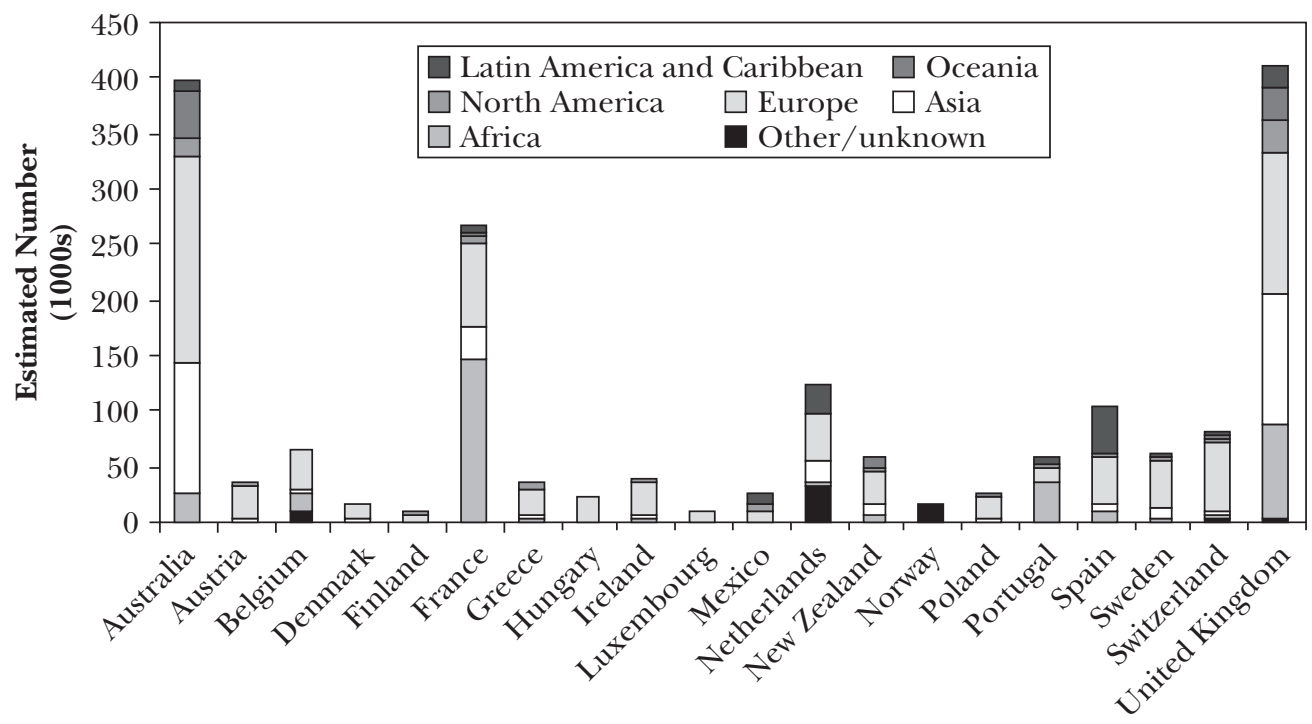

Country of Residence

Figure 1 Estimates of professionals in OECD states by continent of origin 
Table 5 Estimates of professionals in OECD states

\begin{tabular}{|c|c|c|c|c|c|c|c|c|}
\hline $\begin{array}{l}\text { Country of } \\
\text { birth }\end{array}$ & Africa & Asia & Europe & $\begin{array}{c}\text { North } \\
\text { America }\end{array}$ & Oceania & $\begin{array}{l}\text { South and } \\
\text { Central } \\
\text { America } \\
\text { and } \\
\text { Caribbean }\end{array}$ & $\begin{array}{c}\text { Other and } \\
\text { unknown } \\
\text { places of } \\
\text { birth }\end{array}$ & $\begin{array}{c}\text { All } \\
\text { countries } \\
\text { of birth }\end{array}$ \\
\hline \multicolumn{9}{|l|}{$\begin{array}{l}\text { Country of } \\
\text { residence }\end{array}$} \\
\hline Australia & 27572 & 115224 & 185319 & 16798 & 43996 & 7300 & 54 & 396263 \\
\hline Austria & 1086 & 3210 & 29100 & 1353 & 189 & 729 & - & 35667 \\
\hline Belgium & 17001 & 2178 & 36584 & 608 & - & - & 8927 & 65298 \\
\hline Canada & - & - & - & - & - & - & - & - \\
\hline Denmark & 849 & 3214 & 11796 & 1369 & 172 & 519 & - & 17919 \\
\hline Finland & 465 & 815 & 6720 & 540 & 105 & 165 & - & 8810 \\
\hline France & 145889 & 30448 & 76128 & 6130 & 755 & 8189 & - & 267539 \\
\hline Greece & 3802 & 2281 & 24627 & 3696 & 2351 & 419 & - & 37176 \\
\hline Hungary & 334 & 973 & 21497 & 436 & 41 & 191 & - & 23472 \\
\hline Ireland & 2259 & 4398 & 27558 & 2835 & 1218 & 279 & 501 & 39048 \\
\hline Luxembourg & 367 & 334 & 10143 & 237 & 21 & 103 & 35 & 11240 \\
\hline Mexico & 194 & 1126 & 6902 & 8062 & 76 & 9810 & 16 & 26186 \\
\hline Netherlands & 5271 & 17656 & 44597 & - & - & 23502 & 31618 & 122644 \\
\hline New Zealand & 5946 & 10890 & 29775 & 3330 & 9207 & 444 & - & 59592 \\
\hline Norway & - & - & 2065 & - & - & - & 15627 & 17692 \\
\hline Poland & 474 & 1500 & 21714 & 327 & 48 & 201 & 420 & 24684 \\
\hline Portugal & 34700 & 1396 & 13593 & 1254 & 103 & 6340 & - & 57386 \\
\hline Spain & 10647 & 4162 & 43548 & 3616 & 496 & 40800 & - & 103269 \\
\hline Sweden & 2220 & 11000 & 42725 & 2345 & 380 & 3500 & - & 62170 \\
\hline Switzerland & 4006 & 5207 & 60913 & 4552 & 637 & 3527 & 1649 & 80491 \\
\hline United & 84125 & 118790 & 126728 & 29553 & 30376 & 19486 & 2423 & 411481 \\
\hline Kingdom & & & & & & & & \\
\hline United States & - & - & - & - & - & - & - & \\
\hline $\begin{array}{l}\text { OECD - } \\
\text { Total }\end{array}$ & 347207 & 334802 & 822032 & 87041 & 90171 & 125504 & 61270 & 1868027 \\
\hline
\end{tabular}

Source: OECD (2008).

\section{Conclusions and Future Directions in Research, Theory, and Methodology}

Skilled migration is an enormous topic and one that merits further research, not least for its relevance to our understanding of new patterns of transnationalism and work, inequality and development. The potential impact of brain drain on these factors may contribute to poverty creation but, equally, recent studies on the importance of remittances have identified how transnational migrants may serve as poverty reduction agents. A central concern about contemporary forms of transnationalism remains the degree to which not only capital but people are able to move within the international system. In this context two important studies have suggested where additional research is particularly warranted.

The first of these studies is Findlay and Lowell's (2002) report for the ILO, which set out several recommendations, including the need to ensure that immigration policies in advanced states facilitate the movement of skilled workers, while encouraging circulation through temporary and return migration and controlling recruitment from "at risk countries." This is an ambitious recommendation that requires further coordination at the global level including refinement of GATS commitments in this 
area. Evidence of good practice and additional insights into the factors which may give rise to more "beneficial brain drain," circulation, and recruitment practices is welcome but it should be noted that, at the time of writing, the balance between state interests and the management of globally considerate migration policies is very much slanted toward advanced economies which have not questioned the effects of their recruitment, both direct and indirect, of skilled migrants on developing states. Rather than promote an agenda for cooperation, there is a marked trend toward inter-state competition over the recruitment of skilled people, and arguably the attraction of skilled migrants is central to states' external economic policies. Even in the context of the European Union, which as a multilateral actor has publicized several initiatives to support those beyond its walls, there is a growing divergence between the various immigration statuses offered by EU member states on the basis of individuals' skills, and little suggestion of genuinely circular migration between the European Union and its eastern neighbors, who remain on the periphery.

The second study focuses on at-risk countries and raises the question of women and their place in both empirical studies and the theoretical literature on skilled migration. Here it is useful to showcase the emerging research on the gendered effects of brain drain by Dumont et al. (2007). In their study of women and brain drain, the authors affirm the positive relationship between high educational status and outmigration of women in developing countries and describe the effects of such migration for development. Relying on econometric estimates which show that emigration of highly skilled women is higher, the poorer their country of origin, they assert that there is a distinctly negative impact when highly skilled women emigrate. Using three key indicators of education and health (infant mortality, under-five years mortality, and secondary school enrolment rate by gender), they conclude that the brain drain of women is especially serious for developing countries where it brings with it the possibilities of poverty-generating conditions. Further analysis of the role of women and the gendered effects of brain drain are therefore of critical importance for both policy development and academic investigation.

Additional research on estimates of skilled migrants, longitudinal studies of circular migration, and analyses of the differentiation of migrants by occupational group and country of origin, and the relative access that such groups enjoy in the receiving state, is also extremely valuable to the study of skilled migration.

\section{References}

Adams, R. (2003) International Migration, Remittances, and the Brain Drain: A Study of 24 LaborExporting Countries. Washington: World Bank.

Alburo, F.A., and Abella, D.I. (2002) Skilled Labor Migration from Developing Countries: Study on the Philippines, International Migration Papers 51. Geneva: International Labor Organization.

Alonso, W. (1976) A Theory of Movements: Introduction. WP-266, Institute of Urban and Regional Development, University of California at Berkeley.

Ballard, K., and Laurence, P. (2004) An Induction Program for European General Practitioners Coming to Work in England: Development and Evaluation. Education for Primary Care 15 (4), 584-95.

Ballard, K.D., Robinson, S.I., and Laurence, P.B. (2004) Why Do General Practitioners from France Choose to Work in London Practices? A Qualitative Study. British Journal of General Practice 54 (507), 747.

Basok, T. (2003) Mexican Seasonal Migration to Canada and Development: A Community-based Comparison. International Migration 41 (2), 3-26.

Beine, M., Docquier, F., and Rapoport, H. (2008) Brain Drain and Human Capital Formation in Developing Countries: Winners and Losers. Economic Journal 118 (528), 631-52. 
Bhagwati, J.N., and Hamada, K. (1974) The Brain Drain, International Integration of Markets for Professionals and Unemployment: A Theoretical Analysis. Journal of Development Economics 1 (1), 19-42.

Blitz, B.K. (1999) Professional Mobility and the Mutual Recognition of Qualifications in the European Union: Two Institutional Approaches. Comparative Education Review 43 (3), 31131.

Blitz, B.K. (2005a) "Brain Circulation," the Spanish Medical Profession and International Recruitment in the United Kingdom. Journal of European Social Policy 15 (4), 363-79.

Blitz, B.K. (2005b) Refugee Returns, Civic Differentiation and Minority Rights in Croatia 1991-2004. Journal of Refugee Studies 18 (3), 362-86.

Boyd, M. (1989) Family and Personal Networks in International Migration: Recent Developments and New Agendas. International Migration Review 23 (3), 638-70.

Briggs, V.M. (2004) Guestworker Programs: Lessons from the Past and Warnings for the Future. Faculty Publications - Human Resource Studies. At www.works.bepress.com/vernon_briggs/100, accessed Jan. 12, 2009.

Briggs, V.M. (2006) Doomed to Fail: The Unintended Consequences of Guestworker Programs (Impact Brief no. 2). Ithaca: School of Industrial and Labor Relations, Cornell University. At www.digitalcommons.ilr.cornell.edu/impactbrief/2, accessed Jan. 12, 2009.

Buchan, J. (2002) International Recruitment of Nurses: United Kingdom Case Study. London: Royal College of Nursing.

Buchan, J., Parkin, T., and Sochalski, J. (2003) International Nurse Mobility: Trends and Policy Implications. Geneva: World Health Organization. At: www.whqlibdoc.who.int/hq/2003/WHO_ EIP_OSD_2003.3.pdf, accessed Jul. 18, 2008.

Cain, G.G. (1976) The Challenge of Segmented Labor Market Theories to Orthodox Theory: A Survey. Journal of Economic Literature 14 (4), 1215-57.

Carrington, W., and Detragiache, E. (1998) How Big Is the Brain Drain? IMF Working Paper 98/102. Washington: International Monetary Fund.

Castles, S., and Kosack, G. (1985) Immigrant Workers and Class Structure in Western Europe. Oxford: Oxford University Press.

Castles, S., and Miller, M.J. (2003) The Age of Migration: International Population Movements in the Modern World. London: Palgrave Macmillan.

Cervantes, M., and Guellec, D. (2002) The Brain Drain: Old Myths, New Realities. OECD Observer, 7.

Chin, R. (2007) The Guest Worker Question in Postwar Germany, Cambridge: Cambridge University Press.

Commander, S., Kangasniemi, M., and Winters, A.L. (2004a) The Brain Drain: Curse or Boon? A Survey of the Literature. In R.E. Baldwin and A.L. Winters (eds.) Challenges to Globalization: Analyzing the Economics. Chicago: University of Chicago Press, pp. 235-72.

Commander, S.J., Chanda, R., Kangasniemi, M., and Winters, A.L. (2004b) Must Skilled Migration Be a Brain Drain? Evidence from the Indian Software Industry (December 2004). IZA Discussion Paper no. 1422. Bonn: Institute for the Study of Labor.

Cornelius, W.A., Espenshade, T.J., and Salehyan, I. (2001) The International Migration of The Highly Skilled: Demand, Supply, and Development Consequences in Sending and Receiving Countries. La Jolla: Center for Comparative Immigration Studies, University of California, San Diego.

De Haas, H. (2008) Migration and Development: A Theoretical Perspective, International Migration Institute, Working Paper 9. At www.imi.ox.ac.uk/pdfs/2009-wp-14-mobility-and-humandevelopment-hein-de-haas, accessed Jun. 4, 2009.

Docquier, F., and Marfouk, A. (2006) International Migration by Education Attainment. In C. Ozden and M. Schiff (eds.) International Migration, Remittances and Development. New York: Palgrave Macmillan, pp. 151-99.

Docquier, F., and Rapoport, H. (2003) Ethnic Discrimination and the Migration of Skilled Labor. Journal of Development Economics 70 (1), 159-72.

Docquier, F., Lohest, O., and Marfouk, A. (2007) Brain Drain in Developing Countries. World Bank Economic Review 21 (2), 193.

Duany, J. (2002) Mobile Livelihoods: The Sociocultural Practices of Circular Migrants between Puerto Rico and the United States. International Migration Review 36 (2), 355-88.

Dumont, J.C., and Lemaître, G. (2005) Counting Immigrants and Expatriates in OECD Countries: A New Perspective, Paris: OECD. 
Dumont, J.C., Martin, J.P., and Spielvogel, G. (2007) Women on the Move: The Neglected Gender Dimension of the Brain Drain. IZA Discussion Paper no. 2920. Bonn: Institute for the Study of Labor.

Elias, P., and Birch, M. (1994) Introduction and the Conceptual Framework of ISCO-88. At www2.warwick.ac.uk/fac/soc/ier/research/isco88/english, accessed Jul. 22, 2008.

Faini, R. (2007) Remittances and the Brain Drain: Do More Skilled Migrants Remit More? World Bank Economic Review 21 (2), 177.

Faist, T. (2000) The Volume and Dynamics of International Migration and Transnational Social Spaces. New York: Oxford University Press.

Favell, A. (2008) Eurostars and Eurocities: Free Movement and Mobility in an Integrating Europe. Oxford: Blackwell.

Findlay, A., and Lowell, L. (2002) Migration of Highly Skilled Persons from Developing Countries: Impact and Policy Responses. International Migration Papers 44. Geneva: International Labor Organization.

Gargiulo, M., and Benassi, M. (1999) The Dark Side of Social Capital. In R.T.A.J. Leenders and S.M. Gabbay (eds.) Corporate Social Capital and Liability. Dordrecht: Kluwer Academic, pp. 298-322.

Global Commission on International Migration (GCIM) (2005) Migration in an Interconnected World: New Directions for Action. Report of the Global Commission on International Migration (October 2005). At www.gcim.org/attachements/gcim-complete-report-2005.pdf, accessed Jul. 18, 2008.

Gregory, P. (1989) The Determinants of International Migration and Policy Options for Influencing the Size of Population Flows. Washington: Commission for the Study of International Migration and Cooperative Economic Development.

Grossman, G.M., and Helpman, E. (1991) Trade, Knowledge Spillovers, and Growth. European Economic Review 35 (2-3), 517-26.

Harris, J.R., and Todaro, M.P. (1970) Migration, Unemployment and Development: A TwoSector Analysis. American Economic Review 60 (1), 126-42.

Hertel, T.W. (1997) Global Trade Analysis Using the GTAP Model. New York: Cambridge University Press.

House of Lords, House of Commons Joint Committee on Human Rights (2006) Highly Skilled Migrants: Changes to the Immigration Rules, Twentieth Report of Session 2006-07. At www.publications.parliament.uk/pa/jt200607/jtselect/jtrights/173/173.pdf, accessed Jul. 24, 2008.

Hunt, J., and Gauthier-Loiselle, M. (2008) How Much Does Immigration Boost Innovation? NBER Working Paper No. W14312 (September). At SSRN: www.ssrn.com/abstract=1264574, accessed Jan. 14, 2009.

Inglehart, R. (1971) The Silent Revolution in Europe: Intergenerational Change in Postindustrial Societies. American Political Science Review 65 (4), 991-1017.

Inglehart, R. (1977) The Silent Revolution: Changing Values and Political Styles among Western Publics. Princeton: Princeton University Press.

Ingelhart, R. (1990) Culture in Advanced Society. Princeton: Princeton University Press.

International Herald Tribune (2008) Cabinet Backs Opening of Border to Professionals, p. 4 (Jul. 17).

International Organization for Migration (2005) World Migration 2005: Costs and Benefits of International Migration. Geneva: IOM.

Iredale, R. (2001) The Migration of Professionals: Theories and Typologies. International Migration 39 (5), 7-26.

Katznelson, I. (2005) When Affirmative Action Was White: An Untold History of Racial Inequality in Twentieth-Century America. New York: Norton.

Khadria, B. (2001) Shifting Paradigms of Globalization: The Twenty-first Century Transition Towards Generics in Skilled Migration from India. International Migration 39 (5), 45-72.

Khadria, B. (2002) Skilled Labor Migration from Developing Countries: Study on India. International Migration Program paper 49. Geneva: International Labor Office.

Kofman, E. (2000) The Invisibility of Skilled Female Migrants and Gender Relations in Studies of Skilled Migration in Europe. International Journal of Population Geography 6, 45-59.

Koser, K., and Salt, J. (1997) The Geography of Highly Skilled International Migration. International Journal of Population Geography 3, 285-303. 
Kritz, M.M., Lim, L.L., and Zlotnik, H. (eds.) (1992) International Migration Systems: A Global Approach. New York: Oxford University Press.

Lavenex, S. (2006) The Competition State and Multilateral Liberalization of Highly Skilled Migrants. In A. Favell (ed.) The Human Face of Global Mobility, International Highly Skilled Migration in Europe, North America and the Asia-Pacific. New Brunswick: Transaction, pp. 29-54.

Lee, E.S. (1966) A Theory of Migration. Demography 3 (1), 47-57.

Light, I., and Bhachu, P. (eds.) (1993) Immigration and Entrepreneurship: Culture, Capital, and Ethnic Networks. New Brunswick: Transaction.

Light, I., Bhachu, P., and Karageorgis, S. (eds.) (1989) Migration Networks and Immigrant Entrepreneurship. Institute for Social Science Research Volume V. 1989-90 - California Immigrants in World Perspective: The Conference Papers, April 1990 (University of California, Los Angeles). At www.repositories.cdlib.org/issr/volume5/1, accessed Jul. 22, 2008.

Linková, M., and Henderson, L. (eds.) (2003) Nurturing or Frustrating Ambition? The Position of Young Researchers in Central and Eastern Europe. Proceedings on the Enwise workshop on young scientists. Prague, April. At www.cec-wys.org/prilohy/aeb76b97/Nurturing\%20or \%20frustrating\%20ambition.pdf?PHPSESSID=5b7dc3c8c94d33560b64fe0c8b294c55, accessed Aug. 10, 2008.

Lowell, B.L. (2002) Some Developmental Effects of the International Migration of Highly Skilled Persons, International Migration Papers 46. Geneva: International Labor Organization.

Lowell, B.L., and Findlay, A. (2001) Migration of Highly Skilled Persons from Developing Countries: Impact and Policy Responses, International Migration Papers 44. Geneva: International Labor Organization.

Mahroum, S. (1999) Competing for the Highly Skilled: Europe in Perspective. Science and Public Policy 26 (1), 17-25.

Mahroum, S. (2002) Europe and the Prospect of Brain Drain. IPTS Report 66. At www.step. no/foton/extranet/litteratur/STR1E666.html, accessed Jul. 12, 2008.

Massey, D.S. (1987) Understanding Mexican Migration to the United States. American Journal of Sociology 92 (6), 1372.

Massey, D.S. (1998) Worlds in Motion: Understanding International Migration at the End of the Millennium. Oxford: Clarendon Press.

Massey, D.S. (1999) International Migration at the Dawn of the Twenty-first Century: The Role of the State. Population and Development Review 25 (2), 303-22.

Massey, D.S., and Espinosa, K.E. (1997) What's Driving Mexico-US Migration? A Theoretical, Empirical, and Policy Analysis. American Journal of Sociology, 102 (4), 939.

Massey, D.S., Arango, J., Hugo, G., Kouaouci, A., Pellegrino, A., and Taylor, J.E. (1993) Theories of International Migration: A Review and Appraisal. Population and Development Review, 19 (3), 431-66.

Massey, D.S., Arango, J., Hugo, G., Kouaouci, A., Pellegrino, A., and Taylor, J.E. (1994) An Evaluation of International Migration Theory: The North American Case. Population and Development Review 20 (4), 699-751.

Mattoo, A., Ozden, C., and Neagu, C. (2005) Brain Waste? Educated Immigrants in the US Labor Market. Washington: World Bank.

Meyer, J.B. (2002) Migration of Skilled and Highly Skilled Workers in South Africa: A Case Study. In International Mobility of the Highly Skilled. Paris: OECD.

Millar, J., and Salt, J. (2008) Portfolios of Mobility: The Movement of Expertise in Transnational Corporations in Two Sectors - Aerospace and Extractive Industries. Global Networks 8 (1), $25-50$.

Mountford, A. (1997) Can a Brain Drain Be Good for Growth in the Source Economy? Journal of Development Economics 53, 287-303.

Mukomel, V. (2008) Trends and Conditions of Brain Drain and Brain Circulation within the Post-Soviet Area: Russia and CIS Countries. Paper presented at the annual meeting of the ISA's 49th Annual Convention, Bridging Multiple Divides, Hilton San Francisco, San Francisco. At www.allacademic.com/meta/p251035_index.html, accessed Jul. 18, 2008.

OECD (2002) International Mobility of the Highly Skilled. OECD Observer Policy Brief (July).

OECD (2008) OECD.Stat. Paris: OECD. At www.stats.oecd.org/wbos/, accessed Jul. 12, 2008.

Overbeek, H. (2002) Neoliberalism and the Regulation of Global Labor Mobility. Annals of the American Academy of Political and Social Science 581(1), 74. 
Parsons, C.R., Skeldon, R., Walmsley, T.L., and Winters, A.L. (2007) Quantifying International Migration: A Database of Bilateral Migrant Stocks. World Bank Policy Research Working Paper no. 4165. Washington: World Bank.

Pellegrino, A. (2001) Trends in Latin American Skilled Migration: "Brain Drain" or "Brain Exchange"? International Migration 39 (5), 111-32.

Pethe, H. (2007) Un-restricted agents? International Migration of the Highly Skilled Revisited. Social Geography Discussions 3, 211-36. At www.soc-geogr-discuss.net/3/211/2007/sgd-3-211-2007. pdf, accessed Jul. 18, 2008.

Petras, E.M. (1981) The Global Labor Market in the Modern World-Economy. In M.M. Kritz, C.B. Keely, and S.M. Tomasi (eds.) Global Trends in Migration: Theory and Research on International Population Movements. Staten Island: Center for Migration Studies, pp. 44-63.

Piore, M.J. (1979) Birds of Passage: Migrant Labor and Industrial Societies. Cambridge: Cambridge University Press.

Piore, M.J. (1983) Labor Market Segmentation: To What Paradigm Does It Belong? American Economic Review 73 (2), 249-53.

Portes, A. (1995) Economic Sociology and the Sociology of Immigration: A Conceptual Overview. In A. Portes (ed.) The Economic Sociology of Immigration: Essays on Networks, Ethnicity and Entrepreneurship. New York: Russell Sage Foundation, pp. 1-41.

Portes, A. (1998) Social Capital: Its Origins and Applications in Modern Sociology. Annual Reviews in Sociology 24 (1), 1-24.

Portes, A., and Borocz, J. (1989) Contemporary Immigration: Theoretical Perspectives on Its Determinants and Modes of Incorporation. International Migration Review 23 (3), 606-30.

Portes, A., and Rumbaut, R.G. (1996) Immigrant America: A Portrait. Berkeley: University of California Press.

Putnam, R.D. (2000) Bowling Alone: The Collapse and Revival of American Community, New York: Simon and Schuster.

Putzel, J. (1997) Accounting for the "Dark Side" of Social Capital: Reading Robert Putnam on Democracy. Journal of International Development 9 (7), 939-49.

Ravenstein, E.G. (1885) The Laws of Migration. Journal of the Statistical Society 48 (2), 167-219.

Regets, M. (2001) Research and Policy Issues in High-skilled International Migration: A Perspective with Data from the United States, IZA Discussion Paper 366. Bonn: Institute for the Study of Labor.

Romer, P.M. (1990) Endogenous Technological Change. Journal of Political Economy 98 (S5), 71.

Romer, P.M. (1994) The Origins of Endogenous Growth. Journal of Economic Perspectives 8 (1), 3-22.

Salt, J. (1992) Migration Processes among the Highly Skilled in Europe. International Migration Review 26 (2), 484-505.

Salt, J. (1997) International Movements of the Highly Skilled. Paris: OECD.

Salt, J. (2005) Current Trends in International Migration in Europe. Strasbourg: Council of Europe.

Salt, J., and Findlay, A. (1989) International Migration of Highly Skilled Manpower: Theoretical and Developmental Issues. In R. Appleyard (ed.) The Impact of International Migration on Developing Countries. Paris: OECD, pp. 159-80.

Salt, J., and Millar, J. (2006) International Migration in Interesting Times: The Case of the UK. People and Place 14 (2), 14-24.

Sana, M., and Massey, D.S. (2005) Household Composition, Family Migration, and Community Context: Migrant Remittances in Four Countries. Social Science Quarterly 86 (2), 509-28.

Sassen, S. (1988) The Mobility of Labor and Capital: A Study in International Investment and Labor Flow. Cambridge: Cambridge University Press.

Sassen, S. (1991) The Global City: New York, London, Tokyo. Princeton: Princeton University Press.

Saxenian, A. (2002) Brain Circulation: How High-skill Immigration Makes Everyone Better Off. Brookings Review 20 (1), 28-32.

Sjaastad, L.A. (1962) The Costs and Returns of Human Migration. Journal of Political Economy $70(5), 80$. 
Skeldon, R. (2005) Globalization, Skilled Migration and Poverty Alleviation: Brain Drains in Context. Brighton: Development Research Centre on Migration, Globalization and Poverty.

Stalker, P. (2000) Workers without Frontiers: The Impact of Globalization on International Migration. London: Lynne Rienner.

Stark, O. (1991) The Migration of Labor. Cambridge: Blackwell.

Steinmann, G., and Ulrich, R.E. (eds.) (1994) The Economic Consequences of Immigration to Germany. Heidelberg: Physica-Verlag.

Stouffer, S.A. (1940) Intervening Opportunities: A Theory Relating Mobility and Distance. American Sociological Review 5 (6), 845-67.

Straubhaar, T., and Wolburg, M. (1999) Brain Drain and Brain Gain in Europe: An Evaluation of the East-European Migration to Germany. Jahrbücher für Nationalökonomie und Statistik 218 (5-6), 574-604.

Thomas-Hope, E. (2002) Skilled Labor Migration from Developing Countries: Study on the Caribbean Region, International Migration Papers 50. Geneva: International Labor Organization.

Tilly, C. (1990) Transplanted Networks. In V. Yans-McLaughlin (ed.) Immigration Reconsidered: History, Sociology, and Politics. New York: Oxford University Press, pp. 79-95.

Todaro, M.P. (1976) Internal Migration in Developing Countries. Geneva: International Labor Office.

Tyers, R., Bain, I., and Vedi, J. (2006) The Global Implications of Freer Skilled Migration, Working Papers in Economics and Econometrics, College of Business and Economics, Australian National University. At www.ecocomm.anu.edu.au/research/papers/pdf/wp468.pdf, accessed Jul. 18, 2008.

United Nations Department of Economic and Social Affairs Statistics Division (2003) ILO's Work with Classifications: Meeting of the Expert Group on International Economic and Social Classifications, New York, 8-10 December 2003. Document no. ESA/STAT/AC.94/518, November. At www.unstats.un.org/unsd/class/intercop/expertgroup/2003/AC94-5.PDF, accessed Mar. 1, 2009.

United Nations Development Program (UNDP) (2007) Fighting Climate Change: Human Solidarity in a Divided World, Human Development Report 2007/8. New York: Palgrave Macmillan.

Vertovec, S. (2000) Rethinking Remittances. Fifth International Metropolis Conference, Vancouver, British Columbia. Working Paper, ESRC Transnational Communities Program, WPTC-2K-15. At www.transcomm.ox.ac.uk/working_papers.htm, accessed Jul. 18, 2008.

Vertovec, S. (2002) Transnational Networks and Skilled Labour Migration. Oxford: Centre for Migration Policy and Society, University of Oxford.

Vertovec, S. (2007) Circular Migration: The Way Forward in Global Policy, Working Paper 4. Oxford: International Migration Institute.

Vertovec, S., and Cohen, R. (1999) Migration, Diasporas, and Transnationalism. Cheltenham: Edward Elgar.

Wallerstein, I. (1974) The Modern World-System. Vol. I: Capitalist Agriculture and the Origins of the European World-Economy in the Sixteenth Century. New York: Academic Press.

Williams, A.M., and Baláž, V. (2005) What Human Capital, Which Migrants? Returned Skilled Migration to Slovakia from the UK. International Migration Review 39 (2), 439-68.

World Trade Organization (WTO) (2008) The General Agreement on Trade in Services (GATS): Objectives, Coverage and Disciplines: Everything You Wanted to Know about the General Agreement on Trade in Services, But Were Afraid to Ask . . At www.wto.org/english/tratop_e/ serv_e/gatsqa_e.htm, accessed Jul. 28, 2008.

Zolberg, A.R. (1989) The Next Waves: Migration Theory for a Changing World. International Migration Review 23 (3), 403-30.

\section{Online Resources}

The Organization for Economic Cooperation and Development (OECD). At www.oecd.org/ topic/0,3373,en_2649_37415_1_1_1_1_37415,00.html, accessed May 18, 2009. One of the most authoritative sources on international migration data, which includes the role of migration in alleviating labor shortages, links between migration, demography, and economic growth, and the fiscal impact of migration. 
International Migration Outlook. At www.oecd.org/els/migration/imo, accessed May 18, 2009. For comparative data and thematic information on trends, national data, policies, and special studies.

OECD.Stat. At www.stats.oecd.org/wbos/, accessed Jul. 12 2008. For statistical information.

The International Labor Office (ILO). At www.ilo.org/public/english/bureau/stat/class/icse. htm, accessed May 18, 2009. Responsible for the International Classification Status in Employment (ICSE).

UNESCO. At www.portal.unesco.org/shs/en/ev.php-URL_ID=1228\&URL_DO=DO_TOPIC\&URL_ SECTION=201.html, accessed May 18, 2009. Houses an important program on International Migration in its Division of Social Sciences, Research and Policy, which aims to promote the respect for the human rights of migrants, and to contribute to peaceful integration of migrants in society.

The Centre for Migration Policy and Society (COMPAS). At www.compas.ox.ac.uk, accessed May 18, 2009. COMPAS (run by the University of Oxford) aims to provide a strategic, integrated approach to understanding contemporary and future migration dynamics across sending areas and receiving contexts in the UK and EU.

The Centre for Research and Analysis of Migration (CReAM). At www.econ.ucl.ac.uk/cream/, accessed May 18, 2009. CReAM is an independent and interdisciplinary research organization located in the Department of Economics at University College London. CReAM's research focuses on the causes, patterns, and consequences of international population mobility and movements affecting the UK and Europe and on associated global processes.

The International Migration Institute (IMI). At www.imi.ox.ac.uk/, accessed May 18, 2009. Based at the University of Oxford, IMI works with researchers, practitioners, and policy makers in the global South and North and is committed to developing a long-term and comprehensive perspective on global migration dynamics.

The Migration Information Source. At www.migrationinformation.org/resource_list.cfm, accessed May 18, 2009. Aims to provide authoritative data from numerous global organizations and governments, and global analysis of international migration and refugee trends. It is managed by the Migration Policy Institute, which is an independent think tank based in Washington, DC, that provides research and information on migration patterns and processes.

The John D. and Catherine T. MacArthur Foundation. At www.macfound.org/site/ c.lkLXJ8MQKrH/b.1494483/k.43AD/Global_Migration_Human_Mobility.htm, accessed May 18, 2009. Among the most prominent private foundations to support research on international migration. Its program on Global Mobility and Human Migration has supported some important research on new patterns of transnational migration in order to improve the governance of international migration and build a base of knowledge about the relationship between migration and economic development.

\section{Acknowledgments}

The author is particularly grateful to Dan Ozarow and Andrew Bell for their research assistance. He also wishes to acknowledge colleagues who commented on earlier versions of this draft, including Caroline Sawyer and ISA editorial team Gallya Lahav, Nukhet Sandal, and two anonymous reviewers. 


\begin{abstract}
About the Author
Brad K. Blitz is Professor of Human Geography at Kingston University, London, and is a Research Associate in the Department of International Development, University of Oxford. He is also director of the International Observatory on Statelessness (www.nationalityforall.org). $\mathrm{He}$ received his $\mathrm{PhD}$ in International Development from Stanford University and has published several studies on migration and comparative politics in the context of European integration, transitions to democracy, brain drain, and post-conflict development. He has served as a consultant to a number of international agencies, including the World Bank, the UN Office of the High Commissioner for Human Rights, Council of Europe, Organization for Security and Cooperation in Europe, as well as several governments. Recent publications include: The Benefits of Citizenship (with Maureen Lynch, 2010), and War and Change in the Balkans: Nationalism, Conflict and Cooperation (2006). Recent articles have appeared in Journal of European Social Policy, Human Rights Review, Citizenship Studies, Journal of Human Rights, Comparative Education Review, Journal of Refugee Studies, Contemporary European History, Journal of Black Sea and Southeast European Studies, and Political Studies. He is currently completing a five country study on freedom of movement and citizenship in Europe and Russia.
\end{abstract}

